\title{
Electronic Aids for Severely Handicapped People
}

\author{
Roger Jefcoate
}

Introduction In recent years the application of developments in electronic technology has been applied to an increasing extent to enable severely physically handicapped people to lead more meaningful lives. I have been involved in these developments and am Britain's only independent specialist in the application of electronic aids. I am consultant to the Government on electronic aids to employment and am consultant to all of Britain's large handicap organisations. I am not supported in any way by any commercial manufacturer and my work is therefore to recommend the most appropriate equipment for the need rather than to sell any particular device.

My lecture starts with the application of simple electrical and electronic aids and develops into some of the more sophisticated devices for those who are especially severely handicapped.

1. I will start with an elderely and severely handicapped lady who suffers from advanced multiple sclerosis which was diagnosed 12 years ago. She is a resident in a special home for disabled people run by the Leonard Cheshire Foundation, a well known international agency setting up special centres where handicapped people may live together as a small community. Because of her increasing disability she could not operate the push button alarm but with a simple breath operated switch, using a pipe stem, she is now able to call for help. When she puffs on the tube an air sensitive switch is operated. This switch is a standard component in electric washing machines.

2. Professor Gwenda Lewis was disabled by polio while she was Professor of Anaesthesia at the Vellore Christian Medical College \& Hospital in South India. Although I have never visited this world famous institution, it has indirectly influenced me to take up the work I am now doing. Dr. Lewis, in this picture (Fig. 1) uses a wireless communication system which uses household wiring and which offers high quality two way communication from room and even from house to house. These simple units, originally developed in

注）紙数の都合上, 写真を一部割愛したため, 理解 しにくい点はご容㩿いただきたい。
Japan, provide new independence for disabled people the world over. This is by far the most common piece of equipment that I recommend when visiting severely handicapped people in their own homes who need special aids.

In addition to offering good quality two way speech, by pressing another button the handicapped person can also call for help.

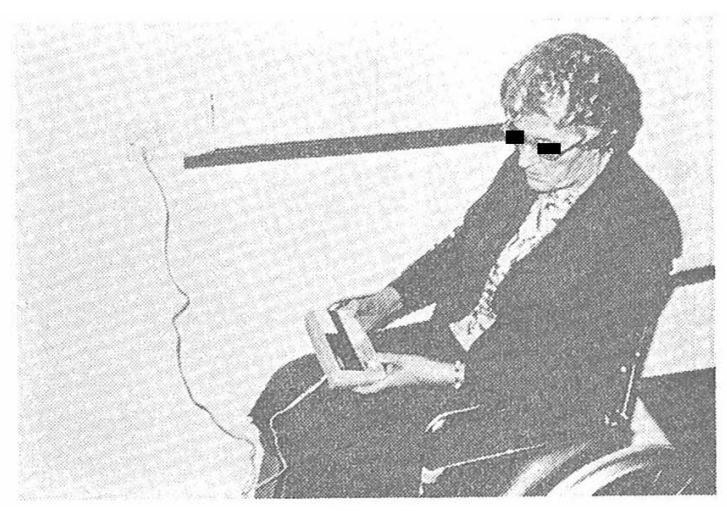

Fig. 1

3. There is another lady who is the former editor of the newspaper of the Leonard Cheshire Foundation. She uses an electrically propelled wheelchair to get around the Cheshire Home where she lives and in this picture is preparing the proofs of a new issue of her newspaper. She suffered from polio many years ago and has considerable respiratory impairment, thus she is unable to call very loudly. Yet she seeks complete isolation when working on the magazine. To call for help, she uses a simple portable alarm unit while she works alone in her office. The device comprises a converted wall mounted switch fitted with an extension lever and this is linked to a standard commercially available battery operated doorbell which is on the floor. It is interesting how often it is possible to adapt, simply, easily and inexpensively, standard commercial devices which can then help handicapped people.

4. Technical aids can help a wide variety of people. There is a similar alarm unit operated this time by a large surface area switch. The user is handicapped 


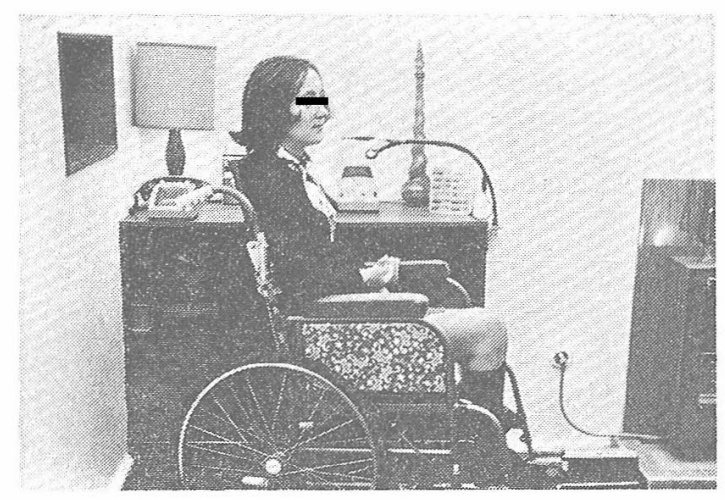

Fig. 2

with osteoarthritis and therefore is suffering some discomfort in addition to her obvious handicap. By the window there is another simple device which is connected to the houschold electrictiy supply. Connected to it also is a table lamp which is lit. The unit by the window, an adapted street lamp photo electric cell, measures the outside light level and at dusk will automatically switch on the table lamp.

5. With more severe handicap, the complexity of electronic aids must increase. At best we should remember it can only compensate to some extent for that disability. Here we see a housewife, a traumatic tetraplegia, level cervical 4, who was injured in a road accident, using the well known Possum equipment (Fig. 2). Possum is Latin for 'I can', and I was one of the original trio who developed this device at the National Spinal Injuries Centre, Stoke Mandeville Hospital. This is a typical installation of an environment control in a disabled person's home. In Britain these installations are paid for by the Government through the National Health Service. She breathes inwards through the tube and an electronic selector through a series of controlled functions. When the required function is reached, she releases the suction and the machine will switch the controlled function. She is able to control items such as light, radio, heater, television, emergency alarm (inside and outside the house) and she can communicate with callers who come to her door and let them in. In addition she is able to make and receive telephone calls. In Britain at least disabled people like to look as normal as is possible and this tidy housewife is very pleased that the equipment that gives her such a dramatic increase in independence is hidden away in that cupboard and so are the 20 or more cables which radiate to various parts of the house. This makes it psychologically more acceptable to the disabled person. All the controls are there but the wires and electronics are invisible. Not every installation, however, is so tidy......

6. Some disabled people find it difficult to be tidy but, nevertheless, he is a remarkably happy man despite

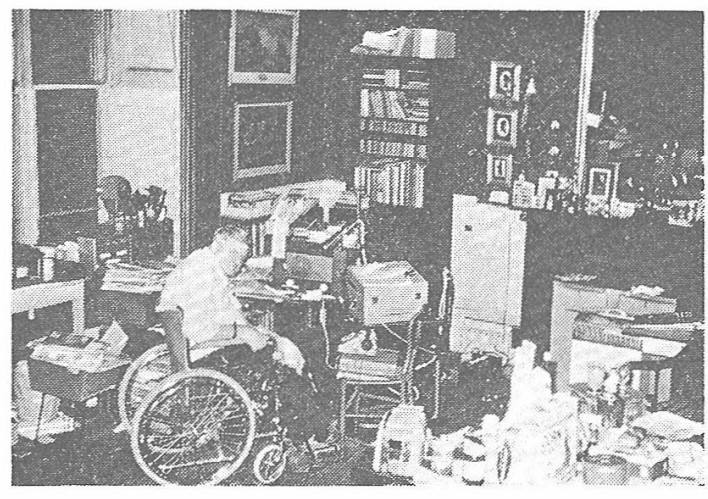

Fig. 3

the mess (Fig. 3). This man has multiple sclerosis diagnosed ten years ago, and because he lives alone he needs a similar control system. The problem in this situation is where to find sufficient space to instal the vitally needed living control unit which will dramatically extend his ability to live in his own home. A drawer under the cupboard full of books in the corner was used!

7. The well known international company, International Business Machines (IBM), operates a scheme whereby reconditioned electric typewriters are issued at especially low cost to severely handicapped people. This world wide scheme was started in Britain. It is now operated throughout Europe and the USA. Is there any company in Japan willing to start such a scheme?

8. There is a boy, 18 years old, with cerebral palsy, who is very intelligent but unable to speak and who is using a typewriter reconditioned under the IBM scheme. It has a raised keyguard which prevents him hitting the wrong keys accidentally and with this equipment he has passed a number of difficult examinations and this year he will join the increasing band of severely handicapped university students.

9. There is a lady who has spent more than 15 years in an iron lung unable to breathe by herself without assistance. She lives in a hospital in Ireland and her great dream was to become a journalist! Thanks to the availability of the right electronic technology, and, equally important, a voluntary organisation willing to purchase it, this lady is now a journalist. She has been so successful that she has nearly raised enough money to repay that original grant for the purchase of her electronic typewriter. She works it by blowing and sucking through a tube and using a simple code. To select a particular letter, she sucks and holds it whilst a control sclector clicks a certain number of times. When the appropriate number has been reached, she lets go and then blows slightly whilst another control selector clicks the required number of times. When she lets go finally the letter is typed. It sounds complicated, but, because the code is frequency distributed, with the items the typist most frequently requires being quickest 


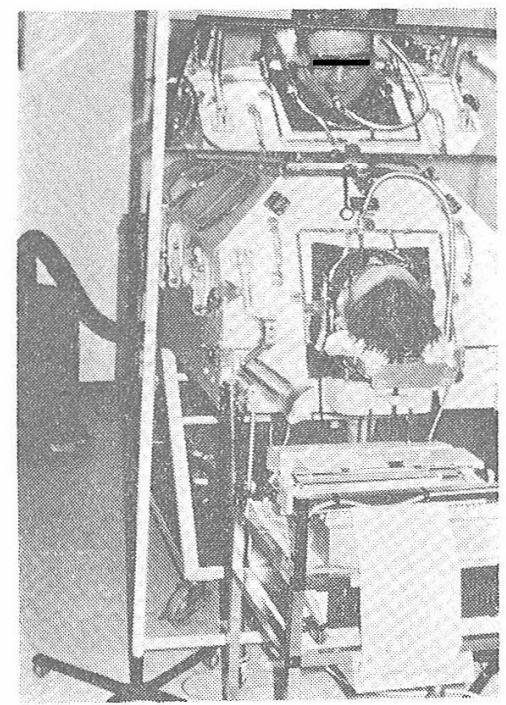

Fig. 4

to get, she can manage up to fifteen words per minute. The selector which makes it all possible is on the lower part of the trolley under the typewriter.

10. This is Dennis Atkin who is Britain's longest lived iron lung user, having been inside this machine since October 1945 (Fig. 4). That is a long, long time. Yet even he has a useful contribution to make to the community and he uses the Electraid electronic typewriter to communicate with his world wide circle of friends and to edit a well known journal for severely handicapped people. He is unable to move anything below his neck and by puffing and sucking on the tube he can use that Electraid typewriter at 18 words per minute. In addition, he uses an environmental control selector to switch on and off his television, light, radio, heater and many other items of domestic equipment, much of it made in Japan. The hospital where he lives built for him a special house, where he has a fine view of the open fields around him and he can see the trees, the animals and the birds. Even though he is so severely handicapped, he remains a remarkably cheerful man.

11. There is another man, aged 32 , who suffers from a rare form of muscular dystrophy known as amyotonia congenita which has left him very badly twisted, and he weighs less than $20 \mathrm{Kgs}$. With suitable equipment, however, he runs a successful accountancy business using his pneumatically controlled electrically propelled wheelchair, an environmental control in his office and, in the background, his electronic typewriter. He works from home and is a successful accountant, specialising in income tax affairs. Because he uses his equipment for earning his living, the British Government purchased the special aids he needed at a cost of over 1 million Yen, and he uses all his equipment to ensure that the same Government gets back as few Yen as possible through his

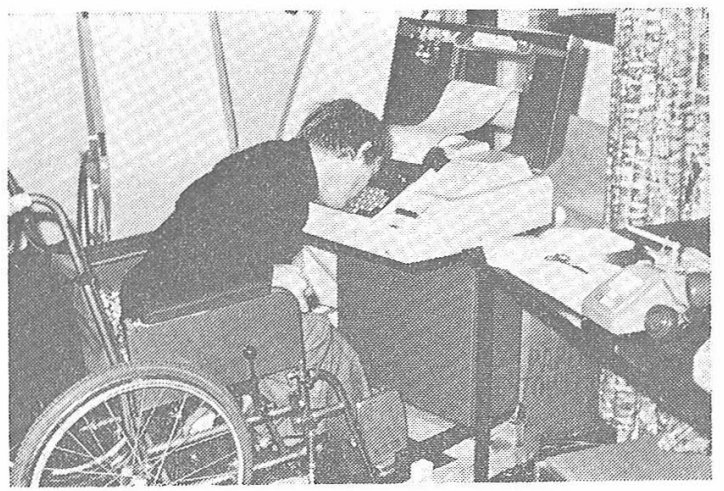

Fig. 5

clients' income tax!

12. It is easy to get too enthusiastic about the role of electronic technology for handicapped people. As far as is possible I urge disabled people to use standard rather than especially modified equipment. In this case, for example, this man, with severe cerebral palsy, used a special electronic typewriter while at school but when he came to do a job of work as in this picture, he found that he could be just as quick operating a standard keyboard with his nose (Fig. 5). He decided that functional ability was more important than dignity and, as a computer programmer for a manufacturer of military hardware he does secret work for the Government. $\mathrm{He}$ is very highly paid indeed and is using his considerable intelligence to earn his living.

13. Michael Rogers is rather similar. He is one of the most handicapped people to come out of Britain's National Spinal Injuries Centre, Stoke Mandeville Hospital. He is paralysed below his neck at the neurological level of cervical $3 / 4$. The only piece of electronic technology that he uses is this electrically propelled wheelchair which has been modified so that he can use it with his chin. His main item of technology is his wooden mouthstick, with which he is able to shave himself, use a telephone, use a dictation machine, a calculator and electric typewriter. $\mathrm{He}$ is even able to type letters, fold them and put them in the envelope and stick the stamp on using the same method! He created medical history last year when he became the first man in the world who was himself severely disabled to write a medical handbook on paraplegia. The book is called 'Paraplegia-a handbook of practical care and advice', and was published in Britain and the USA. He manages very well indeed with the minimum of technological aids.

14. Now for a complete change. We move to a delightful sunny day in a British country town. This is Wallingford in Oxfordshire and we are looking at the staff training centre run by Britain's largest voluntary agency concerned with handicap, The Spastics Society. Some of you may well have heard my friend, Mr. Bill 


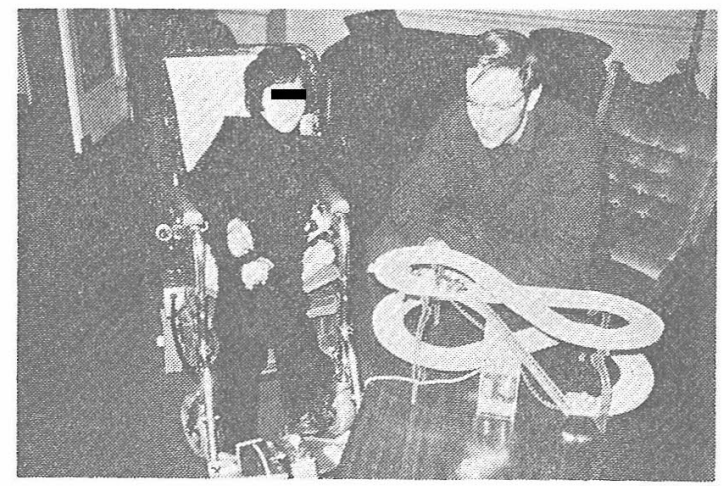

Fig. 6

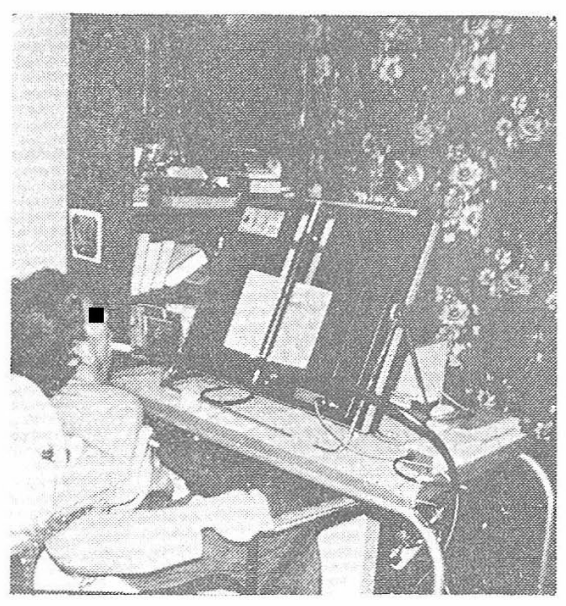

Fig. 8

Hargreaves, when he came last year. Once a year I run a course at this centre dealing exclusively with the application of electronic technology to the needs of severely handicapped people. Because it is the only course of its kind in Europe, it attracts visitors from all parts of the world for this one week's intensive course. In addition I arrange a full supplementary programme of visits to schools, centres and other specialised institutions concerned with handicap, both before and after the course. However, I should emphasise that the number of places available is very restricted, so early application is important.

On the course we concern ourselves with practical technology and here we see a typical example. This four years old cerebral palsied child is learning to recognise the relationship between words and objects using special cards. She presses the switch lightly and the rotary indicator turns until the pointer reaches the item requested by the teacher. Tragically, she cannot speak and will almost certainly need special aids for the rest of her life.

15. Play is a fundamental part of developmental

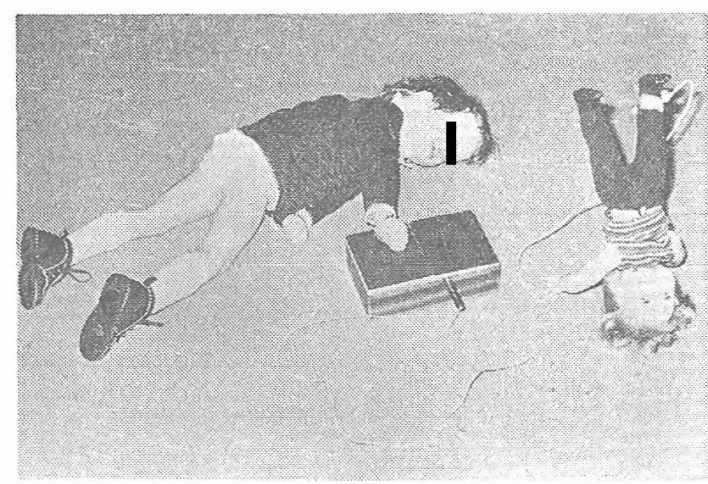

Fig. 7

learning and it is even more important for physically and mentally handicapped children. Sadly, there are very few commercially available toys and games which are suitable for such children and this means that many are denied this opportunity. However, in Britain there is an international organisation called 'ACTIVE' which brings together teachers, therapists, technicians and, above all, relatives of handicapped people to design, develop and modify toys, games and other leisure aids for handicapped people. 'ACTIVE' is now building a design index and issues a newsletter three times a year. Membership costs 1,500 Yen.

It is possible to modify commercially available toys for the very severely physically handicapped child. Many of these toys originate in Japan. They are great fun but hopeless for disabled people. However, by using heavy duty industrial switches, it is possible to give this young man the chance of having fun, for the first time in his life, by operating this toy for himself. On the technology course, we have a workshop session and this particular toy was modified by this child's teacher who had never used a soldering iron in her life before! The child is 12 years old, is completely unable to speak, has cerebral palsy and plays on his own for the first time in his life (Fig. 6).

16. It is important to help severely handicapped children at the earliest possible age. This two years old cerebral palsied girl wants to play with her doll, yet she is physically incapable of doing so (Fig. 7).However, by modifying the doll and making especially large and easy to operate wooden switches to control it, she can make it turn somersaults. She is using herself physically and mentally, is enjoying herself and at the same time she is reducing her physical and mental disability. Already we are discovering in Britain that by applying simple toys like this at a young age, such children may never need sophisticated and expensive electronic aids in later years.

17. On the technology course we cover a wide range of electrical and electronic aids including aids to mobility. Young children, generally do not like clinical 


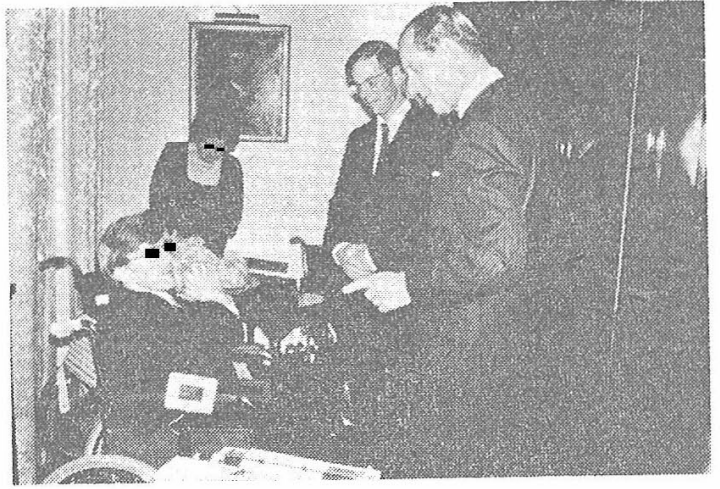

Fig. 9

looking wheelchairs. They much prefer brightly coloured exciting, fast moving, electrically propelled vehicles which can sometimes make their non handicapped friends wish to have them too! These vehicles have been developed by the Department of Mechanical Engineering at London. University using a 12 volt battery, a 12 volt motor and a proportional solid state electronic controlled system. They are very popular indeed with the children who are able to enjoy a fascinating new sport for handicapped people in Britain, namelywheelchair dancing.

18. For those who cannot turn pages of books, this page turning equipment can help them enjoy reading more and also in education and at work (Fig. 8). This one works by simply sucking lightly through a tube and will even turn paperback books. It is based on a roller which picks up the edge of the page before turning it over. I have yet to see a 100 percent reliable page turner but this one seems to be more successful than most.

19. Communication is a fundamental need for every person. It is tragic indeed when a severely disabled is unable to speak. Happily, in recent years portable speech substitute devices have been developed. Most recent is the well known Canon Communicator developed in Japan. This is popular with ambulant handicapped people but in Britain we have a selection of other systems which are more appropriate for more severely physically handicapped people. Here we see the Dutch Elkomi portable communicator with a raised keyguard. Pressing the keys will show on a calculator like display the letters and words which the child wishes to say.

20. There is perhaps the world's best known communicator, and the first such device invented, called the Lightwriter. This device, the size and shape of a portable typewriter, has a waterproof keyboard because some handicapped people unable to speak cannot control dribbling. What the child is trying to say here is shown on the red line to the left of the picture. This communicator will hold 32 characters, is battery operated and sits very conveniently on a tray in front of the disabled

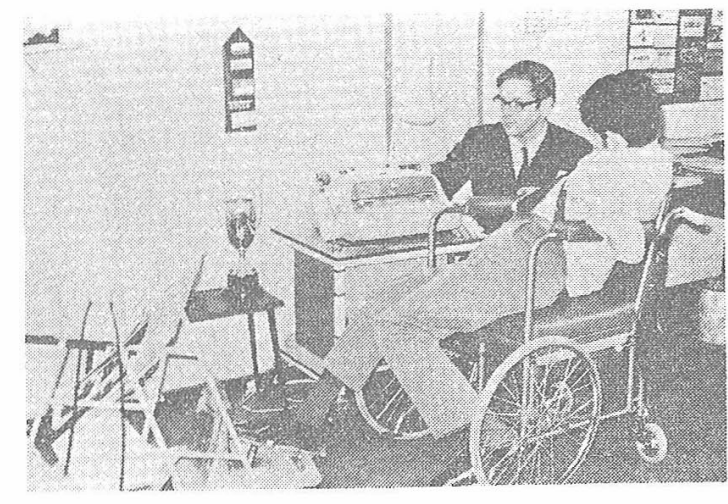

Fig. 10

person. It was invented by a man who, while a student of electronics at university, had an undiagnosed virus diesase which robbed him of the power of speech. He is also in a wheelchair and is only able to move one arm.

21. Another one is probably the world's most versatile electronic typewriter, the Electraid. So far as I know this is the only machine anywhere which can be programmed by the teacher or therapist to provide a continuing physical and mental challenge to the handicapped user. It can be operated by just one switch, or as many as eight switches, so it can be precisely matched to the particular disability of the user. Because it is so versatile, it is very successful as an assessment machine in schools and centres for handicapped people. With all equipment like this it is important to maximise the residual ability of the handicapped person. First and foremost I look not at the handicapped person's handicap but at what they can do. Then it is necessary to match the most appropriate electronic device carefully, using switches. The inventor of this remarkably versatile Electraid typewriter is a wheelchair user and it gave me great pleasure recently to introduce him to His Royal Highness, Prince Philip, who, as many of you may know, is very interested in technology (Fig. 9).

22. Britain's Spastics Society runs Family Services \& Assessment Centre in Central London. There severely handicapped people with cerebral palsy can go with their families to have their physical and intellectual ability assessed and then matched with special aids, where needed. It is a fascinating centre to visit, should you ever come to London. You would be welcome to watch an assessment in progress and to visit the Aids Centre in the basement. In additoin it has overnight accommodation. This is reasonably priced and is very pleasant. It is open to any one of you, whether handicapped or not, but it is most important to write in advance and check that accommodation is available on the dates you have in mind. However, if you are lucky, you might get a room with a view of London's major landmark, the Post Office Tower.

23. I conclude with a picture of my friend, Dick 
Boydell, the first person with cerebral palsy ever to use sophisticated electronic technology (Fig. 10). We see him here doing computer programming work for one of the world's major car manufacturers and he does it with his feet.

With a severely physically handicapped person, it is important, I stress, to look for their abilities and when I visit it is only when I have confirmed what such a person can do that $\mathrm{I}$ begin to look for ways in which electronic aids can compensate, only to some extent, for what that person cannot do. In Dick's case, he can only use his right foot effectively, so that was used as the control source for his electronic typewriter in the background. He taught himself computer programming (having been educated by his loving parents at home) and the cup in the background is the Spastics Society's first ever Achievement Award. Dick uses his remarkable mind rather than his very disabled body to make himself useful. It is electronic technology that has freed his mind and turned him into a useful and contributing member of society.

お知らせ

昭和 55 年度における各種講習会計画

\begin{tabular}{|c|c|c|c|}
\hline 開 催 月 & 講習会種別 & 受講資格 & 講習期間 \\
\hline 昭和55年 4 月 & $\begin{array}{l}\text { 肢体不自由児施設看護管理 } \\
\text { 講習会 }\end{array}$ & 肢体不自由児施設に勤務する総婦長 & $\begin{aligned} 3 \text { 日 } 4 \text { 月 } 21 \text { 日(月) } \\
\sim 23 \text { 日(水) }\end{aligned}$ \\
\hline 5 月 & $\begin{array}{l}\text { 肢体不自由施設看護指導者 } \\
\text { 講習会 }\end{array}$ & $\begin{array}{l}\text { 肢体不自由児施設に勤務する主任看護婦 } \\
\text { 芳び病楝婦長 }\end{array}$ & $\begin{array}{c}\text { (1) } 5 \text { 月16日 (金) } \sim \\
24 \text { 日 }\end{array}$ \\
\hline 6 月 & $\begin{array}{l}\text { リハビリテーション看護実 } \\
\text { 務講習会 }\end{array}$ & $\begin{array}{l}\text { 肢体不自由児施設に勤務する看護婦及び } \\
\text { 准看護婦 }\end{array}$ & $\begin{array}{c}\text { (2) } 6 \text { 月13日 }(\text { 金) } \sim ~ \\
28 \text { 土 }\end{array}$ \\
\hline 7 月 & 重障施設職員講習会 & 重障施設に勤務する看護婦及び准看護婦 & $\begin{array}{c}\text { (1) } 7 \text { 月10日 }(\text { 条) } \sim \\
17 \text { 日 }(\text { 木 })\end{array}$ \\
\hline 8 月 & 休灭 & & \\
\hline 9 月 & 療育職員講習会 & $\begin{array}{l}\text { 肢体不自由览施設に勤務する览童指導 } \\
\text { 員, 保母，ケースワーカー }\end{array}$ & $\begin{array}{l}\text { (2) } 8 \text { 月29日 (金) } \\
9 \text { 月13日 圭) }\end{array}$ \\
\hline 10月 & 通園施設職員講習会 & 夫々の通園施設で直接患児に接する職員 & $\begin{array}{c}\text { (1) } 10 \text { 月17日 }(\text { 金) } \\
25 \text { 日 }( \pm)\end{array}$ \\
\hline 11月 & $\begin{array}{l}\text { リハビリテーション看護実 } \\
\text { 務講習会 }\end{array}$ & $\begin{array}{l}\text { 肢体不自由児施設に勤務する看護婦及び } \\
\text { 准看護婦 }\end{array}$ & $\begin{array}{c}\text { (2)11月 } 7 \text { 日 (金) } \\
22 \text { 日 }\end{array}$ \\
\hline 12月 & 機能訓練講習会 & $\begin{array}{l}\text { 肢体不自由児施設に勤務する機能訓練関 } \\
\text { 係職員 (助手) }\end{array}$ & $\begin{array}{c}\text { (2)12月 } 5 \text { 日 }(\text { 金) } ~ \\
20 \text { 日 }( \pm\end{array}$ \\
\hline 昭和56年 1 月 & 療育職員講習会 & $\begin{array}{l}\text { 䓩体不自由児施設に勤務する児童指導 } \\
\text { 員, 保母, ケースワーカー }\end{array}$ & $\begin{array}{l}\text { (2) } 1 \text { 月 } 23 \text { 日 }(\text { 金) } \sim \\
2 \text { 月 } 7 \text { 日 }\end{array}$ \\
\hline 2 月 & $\begin{array}{l}\text { リハビリテーション看護実 } \\
\text { 務講習会 }\end{array}$ & $\begin{array}{l}\text { 肢体不自由児施設に勤務する看護婦及び } \\
\text { 准看護婦 }\end{array}$ & $\begin{array}{c}\text { (2) } 2 \text { 月13日 (金) } ~ \\
28 \text { 日 } \\
\text { 土 }\end{array}$ \\
\hline 3 月 & 休名 & & \\
\hline
\end{tabular}

備考 日時期間については変更する場合あり.

問合せ先 : 肢体不自由児療育技術者養成所

○の中の数字は週を示す。

焉 173 東京都板橋区小茂根 1-1-10 整肢療護園内

03 (974) 2146 内線 257 